\title{
The effect of Rabies Infection and Vaccination on Pregnancy in Rats as Animal Model
}

\author{
Amani, A. Saleh, A. F. Soliman, A. M. Albehwar, M. B. Shendy \\ Veterinary Serum and Vaccine Research Institute, Abassia, Cairo.
}

\begin{abstract}
The effect of rabies infection and vaccination on pregnancy was investigated in different groups of pregnant rats as an animal model. Intracerebral and intramuscular experimental infection with CVS rabies virus strain was applied on four pregnant rats groups at the middle (seven days after mating) and late stages of gestation (14 days after mating). Subcutaneous rout vaccination of other three pregnant rat groups five to seven days before; seven and 14 days after mating with the inactivated cell culture local rabies vaccine. Each group of infected rats showed clinical signs of rabies although their fetuses did not show any abnormalities. Virus recovery from the placenta and fetuses from dead and sacrificed animals failed to induce rabies signs in mice inoculated intracerebrally with placenta and fetus suspensions while brains of infected dams; through the routes; revealed positive FA by using fluorescent antibody technique. Vaccinated pregnant rats did not show any abnormalities with normal fetuses and good levels of specific rabies antibodies when estimated by serum neutralization test. These findings indicate that rabies vaccination of pregnant animals is safe and it could be recommended to protect both of dams and their offspring in the first months.
\end{abstract}

Rabies is a zoonotic disease affects the central nervous system (CNS), provokes acute and fatal encephalitis in its mammal hosts. The disease etiologic agent is the rabies virus (RABV) which is a neurotropic RNA virus belongs to the order Monoegavirales, family Rhabdoviridae; genus lyssa-virus (Fauquet et al., 2005). Various mammals act as reservoir for RABV in different parts of the world, particularly those from the order Carnivora and Chiroptera (Rupprecht et al., 2002).

Transmission usually occurs when infected saliva deposited in a bite wound or skin scratches, and breached mucous membranes. Less common routes of transmission include aerosol infection in bat caves, ingestion of an infected carrier and transplacental infection. Transmission has occurred in man following transplants of corneas taken from infected patient. Not all animals or humans bitten contract the infection. The severity, location, and multiplicity of bites inflicted on the victim, biotype of the virus and the susceptibility of the recipient influence the outcome of potential exposure to infection. Bites on head and neck are associated with shortest incubation period "IP" (Cornwell, 1994; Green and Rupprecht, 2006). It was stated that natural transplacental transmission of RABV are rare and difficult to confirm. Reports of prenatal infection by rabies virus usually follow experimental infection of dam where by unnatural large inoculums may enter circulatory system (Constantine, 1986). However the possible routes of RABV transmission among bats has include aerosol transmission, ingestion of virus-infected milk from an infected dam and transplacental infection (Smith et al., 1963; Constantine et al., 1968a ; Allendorf et al., 2011). It was suggested that occurrence of rabies in calves less than one year of age may be due to insufficient colostral immunity or because the animals had not received a rabies vaccine or the appropriate booster (Lemos et al., 2001; Mori et al., 2004; Lima et al., 2005).

The present study aims to investigate the effect of rabies virus infection and rabies vaccination on pregnancy and fetuses simulating in rats.

\section{Viruses.}

\section{Material and methods}

Challenge virus strain (CVS). Mice brain adapted rabies virus with a titer of $6.5 \log _{10}$ $\mathrm{MID}_{50} / \mathrm{ml}$ was supplied by the Department of Pet Animal Vaccine Research (DPAVR); Veterinary Serum and Vaccine Research Institute (VSVRI), Abassia, Cairo and used for experimental infection of pregnant rats and challenge of vaccinated pregnant rats.

Cell culture adapted rabies virus. ERA strain of rabies virus adapted to BHK-21 cells of a titer $7 \log _{10} \mathrm{TCID}_{50} / \mathrm{ml}$ was supplied by DPAVR and used in serum neutralization test to estimate the induced antibody titers in vaccinated rats. 
Rabies vaccine. Inactivated cell culture rabies vaccine (ERA strain) was supplied by DPAVRVSVRI and used for rat vaccination.

\section{Animals.}

Mice. Specific pathogen free Swiss albino mice (3-5 weeks old) were randomly divided into eight groups (12 mice /group) and used in virus recovery from experimentally infected rats and their fetuses.

Rats. Specific pathogen-free female rats (9-10 weeks old) were divided into four groups as follow:

Group-one was vaccinated with rabies vaccine using a dose of $0.5 \mathrm{ml} /$ rat inoculated subcutaneously where four rats were vaccinated at the pre-stage of gestation (5-7 days before mating); six rats were vaccinated at the midstage of gestation ( 7 days after mating) and six rats were vaccinated at the late stage of gestation (14 days after mating). These rats were mated at the ratio of one male: two females with a bedding autoclaved wood shaving.

Group-two included five rats experimentally infected with the challenge virus strain (CVS) at the mid stage of gestation (7 days after mating) and seven rats at the late stage of gestation (14 days after mating) through the intracerebral route using a dose of $5 \mathrm{LD}_{50} / \mathrm{rat}$.

Group-three included eight and five rats experimentally infected intramuscularly with the same virus dose at the mid and late stage of gestation respectively.

Group-four included five pregnant rats kept without infection or vaccination as control.

Mice and rats were supplied by DPAVRVSVRI and kept under hygienic measures in separate cages receiving balance ration and adequate water.

Blood samples. Blood samples were collected from all animal groups three times on week intervals post vaccination or infection through the eye canthus route, then serum was separated, inactivated at $56^{\circ} \mathrm{C}$ for 20 minutes and subjected to estimate rabies serum neutralizing antibody titer using serum neutralization test (SNT).

Serum neutralization test (SNT). SNT was carried out to estimate rabies serum neutralizing antibodies in test rats using BHK cell culture as described by Yoneda et al., (2008) and the antibody titer was determined as the reciprocal of the final serum dilution which neutralized and inhibited the cytopathic effect (CPE) of 100 $\mathrm{TCID}_{50}$ of rabies virus.

Virus recovery. As a test to confirm that the observed signs and deaths of infected pregnant rats; fetal and placental specimens were collected from dead animals while vaccinated and survived infected rats were sacrificed by bleeding under deep anesthesia 20 days post mating. Such specimens were homogenized and prepared as $10 \%$ tissue suspension where $0.03 \mathrm{ml}$ of the prepared suspensions were inoculated intracerebrally in each of five mice and kept under daily observation for 30 days according to Steece and Calisher (1989). Brains of mice showing rabies signs or dead were aseptically collected in sterile saline and frozen at $-70^{\circ} \mathrm{C}$. $10 \%$ mice brain suspension was prepared and clarified by low speed centrifugation where the supernatant was re-inoculated intracerabrally into each of other five mice/ sample.

Fluorescent antibody technique (FAT). Impression slides were prepared from each brain of dead mice or mice showing rabies signs and stained with rabies hyper immune serum conjugated with flourescin isothiocyanate supplied by DPAVR-VSVRI to detect rabies antigen. Direct FAT was carried out according to Vogt (1967).

\section{Results and discussion}

The present obtained results revealed that all the pregnant rats infected intracerebrally in the middle stage of gestation (7 days after mating) and in the late stage (14 days after mating) showed clinical signs of rabies represented by nervous movement with erected tail followed by paralysis of the hind limbs and tail (photo 1). The pregnant rat groups that intramuscularly infected and vaccinated were sacrificed 20 days after mating where their fetuses were collected through hysterectomy.

Morbidity and mortality of fetuses are summarized in table (1). The obtained fetuses from pregnant rats infected either intracerebrally or intramuscularly in the late stage of pregnancy, were found to be within the normal average of number; body size; movement and morphological features without placental abnormalities.

Also the fetuses of pregnant rats infected intramuscularly during middle stage of pregnancy; were within the normal parameters. On the other side, in case of intracerebrally infected pregnant rats at the middle stage of gestation, 18 out of 24 fetuses were found dead showing delayed development. Although there are a little data that discuss the vertical transmission of rabies from infected dams to their offsprings, Smith et al., (1963); Constantine et al., (1968a) demonstrated transplacental 
transfer of rabies virus in bats under laboratory conditions suggesting that such infection does not occur under natural conditions (Constantine, 1986).

Table (1): Vertical transmission of rabies virus in pregnant rats.

\begin{tabular}{|c|c|c|c|c|c|}
\hline \multirow[b]{2}{*}{ Rat Groups } & \multirow{2}{*}{$\begin{array}{c}\text { Gestation } \\
\text { stage at } \\
\text { infection time } \\
\end{array}$} & \multirow{2}{*}{$\begin{array}{l}\text { Number of } \\
\text { pregnant } \\
\text { rats } \\
\end{array}$} & \multirow{2}{*}{$\begin{array}{c}\text { Mean } \\
\text { number of } \\
\text { fetuses }\end{array}$} & \multirow{2}{*}{$\begin{array}{c}\text { Dead / total } \\
\text { fetuses } \\
\text { number } \\
\end{array}$} & Rabies virus recovery \\
\hline & & & & & $\begin{array}{c}\text { From } \\
\text { placenta }\end{array}$ \\
\hline \multirow{3}{*}{ 1: Vaccinated } & Pre & 4 & 6 & $0 / 24$ & \multirow{8}{*}{$\begin{array}{c}\uparrow \\
\text { The virus could not be } \\
\text { recovered } \\
\downarrow\end{array}$} \\
\hline & Mid & 6 & 7 & $0 / 42$ & \\
\hline & Late & 6 & 6 & $0 / 36$ & \\
\hline \multirow{2}{*}{ 2: I/C infected } & Mid & 5 & 5 & $18 / 25$ & \\
\hline & Late & 7 & 7 & $3 / 49$ & \\
\hline \multirow{2}{*}{ 3: $\mathrm{I} / \mathrm{M}$ infected } & Mid & 8 & 7 & $2 / 56$ & \\
\hline & Late & 5 & 6 & $1 / 30$ & \\
\hline 4: Control & & 5 & 6 & $0 / 30$ & \\
\hline
\end{tabular}

Table (2): Mean rabies serum neutralizing antibody titers in pregnant vaccinated rats.

\begin{tabular}{lcccc}
\hline Vaccinated Pregnant Rat & \multicolumn{4}{c}{ Mean rabies serum neutralizing antibody titer*/weeks post vaccination } \\
\cline { 2 - 5 } Groups & 1WPV** & 2WPV & 3WPV & 4WPV \\
\hline 5-7 days before mating & 8 & 16 & 32 & 64 \\
7 days after mating & 4 & 8 & 16 & 32 \\
14 days after mating & 8 & 16 & 32 & 64 \\
Unvaccinated control & 0 & 0 & 0 & 0 \\
\hline
\end{tabular}

*Rabies serum neutralizing antibody titer $=$ the reciprocal of the final serum dilution which neutralized and inhibited the $\mathrm{CPE}$ of $100 \mathrm{TCID}_{50}$ of rabies virus.

$* * \mathrm{WPV}=$ week post vaccination.
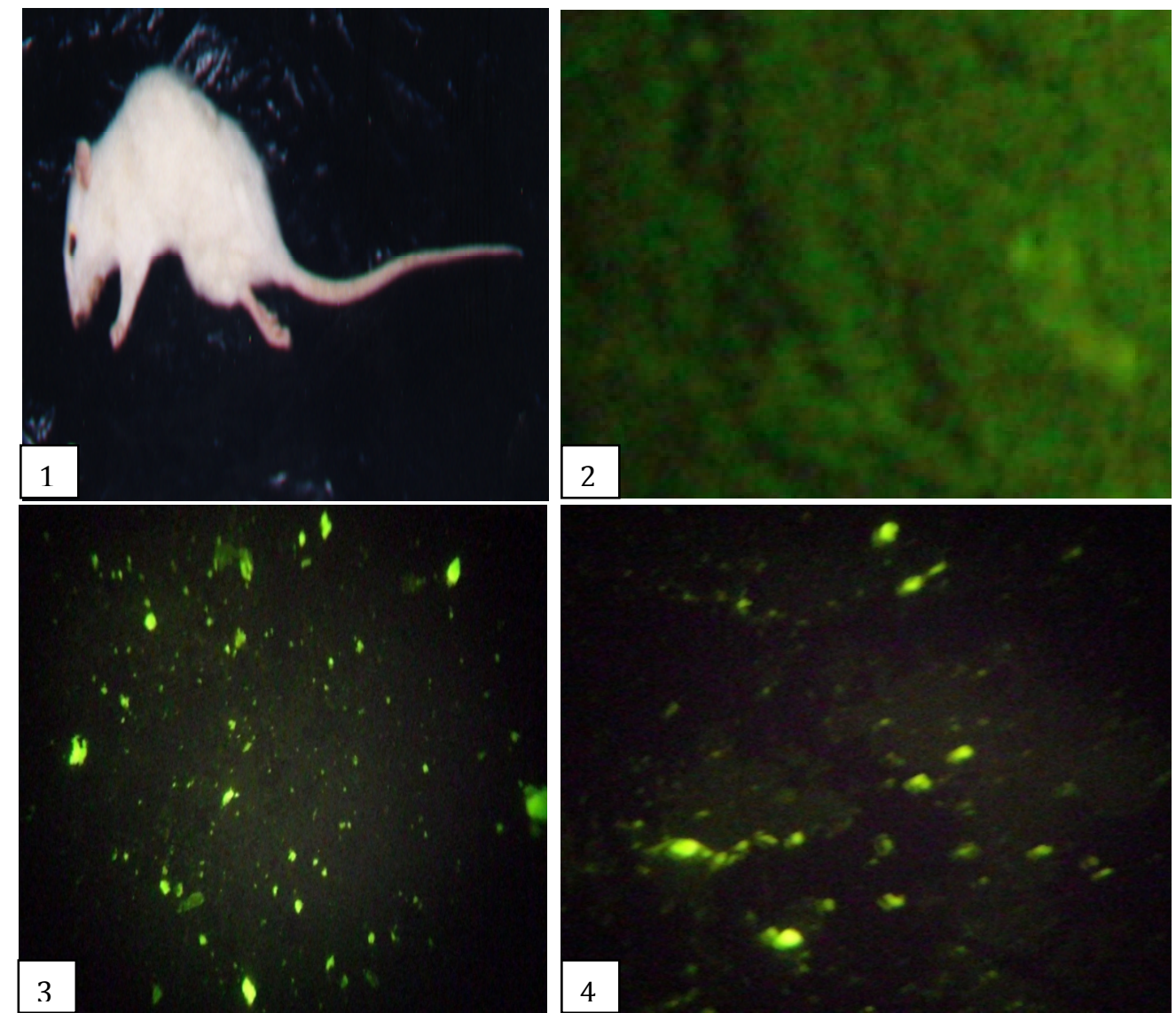

Photo (1): pregnant rat infected intracerebrally in the middle stage of gestation showed paralysis of the hind limbs.

Photo (2): placenta and fetuses impression of infected pregnant rat showed negative FA reaction.

Photo (3 and 4): Brain impressions of both intra-cerebrally (3) and intramuscularly (4) rabies infected female rats showed positive (FA). 
On the other side, all mice inoculated with tissue suspensions prepared from placenta and fetuses from infected pregnant rats in all infected groups, did not show any signs of rabies infection up to 14 days post infection. In addition, FAT did not show positive reaction when carried out on placenta and fetuses impression from all infected pregnant rat groups (photo 2). Brain smears prepared from intracerebrally and intramuscularly infected pregnant rats; died or sacrificed 20 days after mating; showed positive FAT (photo 3 and 4, respectively). Similar findings were recorded by Steece and Calisher (1989) confirming that observed signs of infected rats with both routes of infection were due to rabies virus infection.

The present results obtained by SNT revealed that all vaccinated pregnant rats did not show any signs of illness and exhibited good levels of specific rabies neutralizing antibodies (table-2). Such findings confirm the safety and potency of the cell culture inactivated rabies vaccine even for pregnant animals as stated by Larghi and Nebel,(1980); El-Karamany (1986); Edries (1994); Edries et al., (2001) and Khodeir and Daoud (2008).

Also vaccination of pregnant dams is a necessary fact where it was suggested that occurrence of rabies in calves less than one year of age may be due to insufficient colostral immunity or because the animals had not received a rabies vaccine or appropriate booster (Lemos et al., 2001; Mori et al., 2004; Lima et al., 2005).

Based on the obtained results, it could be recommended to vaccinate pregnant female animals during the middle stage of gestation with inactivated rabies cell culture vaccine to provide them with good levels of immunity that could be available for their offspring.

\section{References}

Allendorf, S. D.; Albas, A.; Cipriano, J.R.B.; Antunes, J. M. A. P.; Appolinário, C. M.; Peres, M. G.; da Rosa, A. R.; Sodré, M. M. and Megid, J. (2011): Rabies virus in a pregnant naturally infected southern yellow bat (Lasiurus ega). J Vet Ani and Toxin including Tropical Diseases, ISSN 1678-9199 volume 17 issue 2 : 223-225.

Constantine, D. G. (1986): Absence of prenatal infection of bats with rabies virus. J Wildlife Dis, 22: 249 - 250.

Constantine, D. G.; Solomon, G. C. and Woodall, D. F. (1968a): Transmission experiments with bat rabies isolates: Responses of certain carnivores to rabies virus from four species of bats. Am J Vet Res, 29: 181-190.

Constantine, D. G. ; Tierkel, E. S. ; Kleckner, M. D. and
Hawkine, M. D. (1968b): Rabies in New Mexico cavern bats. Pub Health Reports, 83: 303-316.

Cornwell, H. J. C. (1994): "Specific infections In: Canine medicine and therapeutics". $3^{\text {th }}$ ed, Chapter 13, pp. 487524, Oxford, Blackwell Scientific Publications, London.

Edries, S. M. (1994): Production of inactivated tissue culture rabies vaccine. Ph.D.Thesis, (Virology). Fac Vet Med, Cairo Univ.

Edries, S. M.; Gurgis, W. I.; Khodier, M. H. and Attyat, M. K. (2001): Preparation of a combined vaccine against canine distemper and rabies. Beni-Suef Vet Med J ,11 (.2) : 237-246.

El-Karamany, R. M. (1986): Production in VERO cells of an inactivated rabies vaccine from strain FRV-K for animal and human use. Acta Virol, 31 (4): 321-328.

Fauquet E. M.; Mayo M. A.; Maniloff J.; Desselgerger U. and Ball L. A. (2005): Virus taxonomy: classification and nomenclature of viruses. Eighth report of the International Committee on the Taxonomy of Viruses. Virus Taxonomy. $8^{\text {th }}$. San Diego: Academic Press; p. 630634.

Green, C. E. and Rupprecht, C. E. (2006): Rabies and other Lyssavirus infections. Infec Dis Dog and Cat., $3^{\text {rd }}$ Ed: 167-183.

Khodeir, M. H. and Daoud, A. M. (2008): Preparation of antirabies hyperimmune serum for emergency immunization of farm animals. $4^{\text {th }}$ Int Sci Conf NRC, 1-9

Larghi, O.P. and Nebel, A.E. (1980): Rabies virus inactivation by Binary Ethyleneimine : New method for inactivated vaccine production. J Clin Microbiol, 2: 120122.

Lemos, R. A. A. A.; Brum, K. B.; Mori, A. E.; Bonilha, M. M.; Katayama, K. A.; Angreves, G. M., and Cavallero, J. C. M. (2001): Doenças caracterizadas por sintomatologia nervosa em bovinos em Mato Grosso do Sul. In: Barros, C.S.L., Lemos, R.A.A., and Cavallero, J.C.M. (Eds.), Manual de procedimentos para diagnóstico histopatológico diferencial da encefalopatia espongiforme bovina (BSE). São Paulo, Lemos. 31- 48.

Lima, E. F.; Riet-Correa, F.; Castro, R. S.; Gomes, A. A. B. and Lima, F. S. (2005): Distribuica das leses no sistema nervosa e epidemiologia da raiva em herbivoros na regiao. Nord do Bras. Pesquisa Vet Brasileir, 25: 250- 264.

Mori, A. E., Lemos, R. A. A. and Kadri, A. R. (2004): Botulismo, meningoencefalite por herpesvirus tipo 5, poliencefalomalacia e ravia. Campo Grande: UFMS, 63.

Rupprecht C. E., Hanlon C. A. and Hemachudha T. (2002): Rabies reexamined. Lancet Infect Dis., 2(6): 32743.

Smith, R. A.; Allen, R. and Sulkin, S. E. (1963): Studies on the pathogenesis of rabies in insectivorous bats: III influence of the gravid state. J Infec Dis, 112: 17-27

Steece, S. R. and Calisher, C. H. (1989): Evidence for prenatal transfer of rabies virus in the Mexico free-tailed bat (Tadarida Brasiliensis Mexicana). J Wild life Dis, 25 (3): 329-334.

Tiffany, B. (2012): Can a Pregnant Dog Be Vaccinated for Rabies? www.Almaseeh2020.com.

Vogt, P. K. (1967): Immunofluorescent detection of viral antigens. Fundamental Techniques in Virology, 316-326.

Yoneda, A.; Tuchiya, K., Takashima, Y.; Arakawa, T.; Tsuji, N.; Hayashi, Y. and Matsumoto, Y. (2008): Protection of mice from rabies by intranasal immunization with inactivated rabies virus. Exp Anim, 57(1): 1-9. 